\title{
GAMBARAN SELF REGULATION PADA MAHASISWI S1 YANG BERPERAN GANDA SEBAGAI IBU BEKERJA
}

\author{
Lamria Sinaga \\ Sekolah Tinggi Diakones HKBP \\ Sinagalamria83@gmail.com
}

\begin{abstract}
This research aims to get a picture of self-regulation in undergraduate students who play a dual role as working mothers. It is also to get a picture of the subject's ability to implement an effective and efficient self-regulation strategy so that the subject avoids the negative impact that will be received. The number of subjects in this study were three people. This study included research descriptive research. According to the method of data collection, this study used cross-sectional research, where data is taken only once in a period of time. Data collection is done by interview and observation methods. The results of this study indicate that the research subjects try to make themselves feel comfortable by following the right path so that subjects can feel happy while undergoing all roles. The relative like husband and other family members make the subjects more enthusiastic in carrying out his dual role.
\end{abstract}

Key Word: Self Regulation, dual role

\begin{abstract}
Abstrak
Penelitian ini bertujuan untuk memperoleh sebuah gambaran tentang kehidupan mahasiswa yang memiliki peran ganda. Tulisan ini juga memberikan sebuah gambaran tentang kemampuan individu dalam melaksanakan peran seefektif dan seefisien mungkin untuk menghindari dampak negatif yang diterima. Responden dalam penelitian inii berjumlah tiga orang. Penelitian ini menggunakan metode kualitatif deskriptif. Metode pengumpulan data adalah dengan cara wawancara dan observasi. Adapun temuan dari penelitian ini adalah responden mencoba untuk membuat dirinya nyaman dengan mengikuti peran ganda tersebut. Keluarga mereka seperti suami dan anggota keluarga lainnya mendorong responden untuk bersikap antusias dan semangat menjalankan perannya.
\end{abstract}

Kata kunci: Regulasi diri, Peran Ganda

\section{PENDAHULUAN}

Pilihan kaum wanita dalam menjalani peran lebih dari satu tentu akanmenimbulkan konsekuensi tersendiri. Untuk menghindari berbagai masalah yang muncul mereka harus mampu mengatur diri mereka sendiri.Dalam ilmu psikologi,manajemen diri lebih dikenal dengan regulasi diri.Regulasi diri berkaitan dengan bagaimana individu mengaktualisasikan dirinya dengan menampilkan serangkaian tindakan yang ditujukan pada pencapaian target.

Regulasi diri yaitu dengan menyatakan bahwa setiap orang meiliki kekuatan untuk bebas menciptakan gaya hidupnya sendiri-sendiri. Manusia diharuskan bertanggung jawab tentang 
siapa dirinya dan bagaimana dia untuk bertingkah laku. Manusia mempunyai kekuatan kreatif untuk mengontrol kehidupan dirinya, bertanggung jawab mengenai tujuan finalnya, menentukan cara memperjuangkan mencapai tujuan tersebut ${ }^{1}$.

Teori sosial kognitifmenegaskan bahwa perilaku manusia secara luas termotivasi dan diatur oleh pengaruh dirinya sendiri.Tujuan hidup menjadi salah satu motivasi terbesar bagi manusia untuk berperilaku. Kepercayaan akan kemampuan diri, mempertimbangkan konsekuensi dari tindakan yang akan dilakukan, membuat tujuan untuk dirinya sendiri, dan merencanakan setiaplangkah untuk mencapai tujuan yang diinginkan merupakan bentuk dari regulasi diri (self-regulation $)^{2}$.

Regulasi dirimerupakan hasil dari adanya sense of personal agency yaitu, rasa dimana seseorang menganggap dirinya bertanggungjawab atas usaha pencapaian hasil.Maka dari itu seseorang membuat pilihan, membuat rencana untuk tindakan, memotivasi dan mengatur jalannya rencana dan tindakan.Regulasi diribertujuan membentuk perilaku positif manusia dalam mencapai tujuan hidupnya dan juga menghentikan tindakan yang tidak seharusnya dilakukan ${ }^{3}$. Regulasi diri memiliki tujuh tahapan yang lebih rinci.Melalui rumusan tujuh tahap inilah kemudian dikembangkan alat ukur short self-regulation questionnaire (SSRQ). Adapun ketujuh tahap regulasi diri adalah (1) receiving, yaitu penerimaan informasi.Merupakan langkah awal individu dalam memperoleh informasi dari berbagai sumber yang diperolehnya. (2) evaluating yaitu proses untuk menyadari seberapa besar masalah tersebut. Pada proses evaluasi ini, individu akan menganalisis informasi dibandingkan dengan masalah yang bersumber dari luar dirinya (external). (3) triggeringyaitu dimana individu akan tergerak untuk melakukan perubahan atas perilakunya. (4) searching(mencari solusi) yaitu individu akan mengurangi pertentangan terhadap suatu masalah yang sedang dihadapinya dengan mencari solusi yang terbaik bagi dirinya. (5) formulating(merancang suatu rencana), individu akan mulai menyusun aspek-aspek pokok yang akan digunakan untuk meneruskan target atau tujuan. (6) implementing (penerapan informasi) yaitu individu segera melakukan tindakantindakan nyata untuk mencapai rencana yang telah dirancang sebelumnya, sehingga tercapai dengan efektif dan sesuai dengan skema yang telah dibuat. (7) assessing(mengukur efektivitas dari rencana yang telah dibuat), individu akan merefleksikan hasil dari implementasi yang telah dilakukan untuk kemudian mengukur efektivitas dan efisiensi dalam pencapaian tujuan.

\footnotetext{
${ }^{1}$ Alwisol, Psikologi Kepribadian (Malang: UMM Press, 2012).

${ }^{2}$ Bandura A, Teori Kognitif Sosial Dan Teori Regulasi Dan Perilaku Manusia (Jakarta: Gramedia, 1991). 50

${ }^{3}$ Alfiana A, D, "Regulasi Diri Pada Mahasiswa Ditinjau Dari Keikutsertaannya Dalam Organisasi

Kemahasiswaan.," Jurnal IImiah Psikologi Terapan 01 (2013). 245-259
} 
Regulasi diri ini perlu dimiliki dan dikembangkan sejak kanak-kanak.Salah satu tugas perkembangan seorang anak adalah berkembang dari external regulation menjadi selfregulation.Self-regulation bekerja melalui seperangkat fungsi psikologikal yang harus dikembangkan dan diarahkan untuk perubahan diri.Dalam pengertian ini regulasi dirimenjadi spesifik pada setiap individu, karena menyangkut kemampuan kognitif dan lingkungan sosial pada masing-masing pribadi dan berkembang seiring dengan perkembangan individu itu sendiri dan lingkungan sosialnya.

Penerapan self-regulation dapat menimbulkan dampak positif maupun negatif, tergantung dari cara yang digunakan. Pada individu yang kurang optimal menerapkan self-regulation dalam kehidupannya akan memunculkan dampak negatif seperti: memicu terjadinya frustasi khususnya di kalangan mahasiswa yang disebabkan oleh tugas-tugas kuliah, kurang optimalnya prestasi belajar yang dicapai oleh siswa dan banyaknya individu yang berpindah pekerjaan karena merasa tidak sesuai. Dampak negatif yang juga akan dirasakan individu yang gagal mengembangkan self-regulation dengan baik yaitu munculnya perilaku agresif pada individu tersebut ${ }^{4}$.

Regulasi diri dalam belajar akan membantu individu dalam memenuhi berbagai tuntutan yang dialamai oleh individu tersebut, dapat membuat individu mampu mengatur tujuan, mengevaluasi dan membuat adaptasi yang diperlukan sehingga dapat mendukung prestasinya. Hasil penelitian lainnya juga menunjuk-kan bahwa regulasi diri dalam belajar mempunyai peranan yang besar dalam pencapaian prestasi akademik seseorang ${ }^{5}$.

Menjadi istri dan ibu dari anak-anak memiliki peran untuk mendampingi dan melayani suami ditambah dengan mengasuh, merawat, mendampingi dan mendidik anakanaknya.Bekerja di luar rumah memiliki tanggung jawab untuk menghasilkan performa kerja yang sesuai dengan tuntutan pekerjaan itu sendiri.Penelitian ini mengangkat kondisi mahasiswi strata satu yang memiliki peran ganda sebagai ibu dan berkerja di luar rumah dan sebagai mahasiswa.Terkait dengan lingkungan sosialnya, maka subyek terlibat dalam lingkungan pendidikan perguruan tinggi, lingkungan keluarga dan juga lingkungan kerja pada periode waktu yang bersamaan.Mahasiswi strata satu dengan peran ganda dapat dipastikan ada pengorbanan otonomi dirinya, mereka perlu mengatur kegiatannya sesuai dengan prioritasnya.

${ }^{4}$ Ibid.

5Zimmerman B. J, "Self Regulated Learning and Academic Achievment: An Overview," Educational Psychologist 25 (1) (1990). 3-17 
Dalam menentukan prioritasnya, mahasiswi perlu menoleh lagi pada komponenkomponen dari self-regulation, standardperilaku yang diinginkannya, motivasi untuk mencapai standard tersebut, bagaimana memonitor situasi dan pikiran yang tidak sesuai dengan standar dirinya dan kekuatan dalam diri menghadapi keadaan yang mendesak. Dengan kata lain mereka dituntut memiliki self-regulation yang baik. Hasil penelitian menunjukkan adanya hubungan yang positif antara self-regulation dengan prestasi akademik, dimana mahasiswa dengan prestasi rendah memiliki self-regulation rendah. Tanpa self-regulation yang baik pada mahasiswi strata satu dengan peran ganda sebagai ibu bekerja, maka sangat memungkinkan terjadinya konflik peran ganda(work family conflict).

Konflik peran ganda merupakan bentuk konflik antar peran yang mana peran pekerjaan dan keluarga membutuhkan perhatian yang sama ${ }^{6}$. Seseorang dikatakan mengalami konflik peran ganda apabila merasakan suatu ketegangan dalam peran pekerjaan dan keluarga. Konflik peran ganda disebabkan karena waktu dan ketegangan, jumlah anggota keluarga, usia anak, banyak kelebihan jam kerja, banyaknya jam kerja di luar rumah, tingkat fleksibilitas jam kerja, tingkat dukungan sosial ${ }^{7}$

\footnotetext{
${ }^{6}$ Aftina Nurul Husna, Frieda N.R. Hidayati, and Jati Ariati, "REGULASI DIRI MAHASISWA BERPRESTASI," Jurnal Psikologi Undip 13, no. 1 (April 15, 2014): 50-63, accessed February 8, 2021, http://ejournal.undip.ac.id/index.php/psikologi/article/view/8066.

${ }^{7}$ Greenhause \& Beutell J H, "Sources Of Conflict Between Work and Family Role Academy of Management" (1985).
} 


\section{METODEPENELITIAN}

Penelitian ini menggunakan pendekatan penelitian kualitatif. Penelitian kualitatif adalah penelitian yang menggunakan latar alamiah dengan maksud untuk memahami fenomena tentang apa yang dialami oleh subyek penelitian secara utuh dengan mendeskripsikan data dalam bentuk kata-kata dan bahasa. Data yang dikumpulkan dalam penelitian ini bukan data dalam bentuk angka-angka melainkan data yang berasal dari wawancara, catatan lapangan, dokumen pribadi, memp dan dokumen lainnya ${ }^{8}$.Tujuan dari penelitian ini adalah memperoleh wawasan dan pengertian mendalam mengenai self-regulation pada mahasiswi yang berperan ganda sebagai ibu bekerja. Menurut cara pengambilan datanya penelitian ini menggunakan cross-sectional research, dimana data diambil hanya satu kali dalam suatu periode waktu.

\section{Subyek Penelitian}

Subyek dalam penelitian ini memiliki karakteristik yaitu wanita dalam kategori dewasa madya yang berusia antara 40-65 tahun merupakan mahasiswi strata satu; sudah menikah dan memiliki anak; dan juga bekerja di luar rumah.Dalam penelitian ini subyek dipilih tiga orang responden yaitu subyek TR, subyek VR dan subyek JN.

1. GambaranSubyek TR

Saat ini subyek sedang menempuh studi strata satu di sebuah sekolah tinggi keguruan dan ilmu.Semester yang ditempuh saat ini adalah semester 6. Kendala dana merupakan yang terbesar sehingga kesempatan menempuh studi strata satu baru dapat dijalani subyek saat ini, terlepas dari tuntutan pemerintah akan latar belakang pendidikan guru.

\section{Subyek VR}

Saat ini subyek sedang menempuh studi strata satu di sebuah sekolah tinggi keguruan dan ilmu pendidikan.Semester yang ditempuh saat ini adalah semester 7. Subyek menjalani kuliahnya hanya pada hari Sabtu, dimulai dari jam 2 siang hingga jam 10 malam.

3. Subyek JN

Subyek menikah dan memiliki anak. Bekerja selama 20 tahun, subyek memiliki keinginan untuk melanjutkan pendidikan strata satu yakni bagian kesehatan masyarakat bidang K3 (Kesehatan Keselamatan Kerja) dengan tujuan ingin memperoleh posisi yang lebih baik

${ }^{8}$ Lexy J Moleong, Metodologi Penelitian Kualitatif (Bandung: Remaja Rosdakarya, 2017). 
lagi ditempat subyek bekerja. Subyek menempuh pendidikan strata satu di sebuah universitas swasta.Saat ini subyek sedang menempuh semester IV.

\section{Instrumen Penelitian}

Pengumpulan data dilakukan dengan cara observasi langsung dan wawancara. Dalam penelitian ini informasi yang diperoleh berupa kata-kata yang diungkapkan subjek secara langsung.Subyek menggambarkan perasaan, pikiran dan pendapatnya yang menjadi informasi yang dibutuhkan dalam penelitian. Wawancara yang dilakukan dalam penelitian ini adalah wawancara mendalam dengan tetap menggunakan pedoman wawancara.

Instrumen yang digunakan pada penelitian ini adalah catatan anekdoktal dengan alat tulis, alat perekam dan handphone, pedoman wawancara dan informed-consent. Informed-consent dan alat tulis digunakan sebagai bentuk kesepakatan yang sah bahwa subyek menyetujui untuk diwawancara tanpa ada paksaan dari pihak lain serta subyek menyatakan data yang diberikan adalah benar adanya. Pedoman wawancara digunakan sebagai panduan peneliti dalam mengajukan pertanyaan-pertanyaan wawancara sehingga arah dari proses wawancara tepat berfokus pada tujuannya. Pedoman ini disusun tidak hanya berdasarkan tujuan penelitian, tetapi juga berdasarkan teori yang berkaitan dengan masalah yang diteliti.

\section{Analisis Data}

Analisis data adalah proses mengatur urutan data, mengorganisasikannya ke dalam suatu pola, kategori dan suatu uraian dasar ${ }^{9}$. Untuk menganalisis data yang diperoleh dalam penelitian ini, maka penulis menggunakan teknis analisis data deskriptif kualitatif yaitu untuk menganalisa data, baik data dari hasil wawancara, observasi maupun dokumentasi kemudian di deskripsikan.Penelitian kualitatif membutuhkan kejelian dan interpretasi atas fenomena yang diketahui di lapangan atas data apa yang ditemukan. Data yang ditemukan diurutkan sesuai dengan kategori pembahasannya masing-masing. Analisis data dilakukan dengan menggunakan deskriptif kualitatif yaitu dengan cara menggambarkan keadaan yang sebenarnya di lapangan.

\footnotetext{
${ }^{9}$ Sugiyono, Metode Penelitian Kualitatif Dan R\&D (Bandung: Alfabeta, 2010).
} 


\section{HASIL PENELITIAN DAN PEMBAHASAN}

Merujuk dari hasil wawancara terhadap ketiga subyek terkait tujuh tahapan regulasi diri, yaitu: Tahap I Penerimaan Informasi (Receiving)Subyek TR dan VR memenuhi unsur tahapan receiving dengan melakukan persiapan awal sebelum menjalani perannya sebagai guru di tingkat sekolah dasar dan mahasiswa strata satu. Sedangkan subyek JN kurang tergali informasi yang menjelaskan proses awal yang dilakukan sebelum menjalani profesinya. Subyek JN hanya menyampaikan bahwa komitmen adalah modal awal sebelum memulai perannya.Tahap II Mengevaluasi Informasi ( Evaluation Information)Subyek TR dan VR memandang kendala pada sisi beban pekerjaan dan perannya sebagai mahasiswa. Kendala pertama, menghadapi anak-anak yang beda karakter. Kendala kedua: biaya. Karena ekonomi masih pas-pasan.Kuliah terbengkalai sampai beberapa tahun.Subyek TR merasa tidak mempunyai konflik saat menjalani ketiga peran ini.Hal ini dapat terjadi karena mendapat pengertian dari suami dan anak-anak.Tahap IIITriggering.Upaya yang dilakukan subyek TR dalam mengatasi kendala yang dihadapi yaitu dengan mencicil pekerjaan rumah tangga dan menjaga kondisi fisiknya.Upaya yang dilakukan subyek VR dalam mengatasi kendala yang dihadapi yaitu memilih sekolah yang jaraknya dekat dengan rumah serta memilih tempat kuliah serta jadwal kuliah yang bersifat fleksibel sehingga dapat menyesuaikan aktivitas dan juga peran yang dijalani.

Subyek VN lebih memandang bahwa untuk mengatasi segala keraguan dan masalah dalam menjalani keseluruhan peran dalam hidupnya yaitu senantiasa berpikir positif dan berusaha dari dalam diri disertai dengan kenyakinan diri bahwa semuanya dapat dijalani dengan baik. Tahap IV Searching Subyek TR, JN dan VN lebih memilih menceritakan kendala atau masalah yang dihadapi khusus jika menyangkut dengan persoalan dengan suami, maka subyek VN memilih menceritakan kepada teman dekatnya. Karena dengan bercerita atau berbagi, maka dapat meringinkan beban pikiran subyek.

Tahap V Formulating, Subyek TR lebih memilah dan memilih kegiatan apa yang sekiranya dapat dilakukan dan diselesaikan, namun apabila tidak merasa mampu untuk diselesaikan, maka akan dilanjutkan pada keesokkan harinya, Subyek VR, formulasi yang diterapkan sebagai upaya meneruskan target atau tujuan yang hendak dicapai yaitu setiap kegiatan yang dilakukan jangan dijadikan sebagai beban, justru harus disenangi, Subjek VN, pengaturan atau formulasi yang diterapkan khususnya dalam mengerjakan pekerjaan rumah tangga yaitu subyek tidak membagi 
tugas secara spesifik kepada setiap anggota keluarga dan diharapkan anak-anak dapat berinisiatif untuk membantu.

Tahap VI Implementing, subyek VR, upaya implementasi yang diterapkan dalam proses regulasi diri supaya tetap terfokus pada tujuan yang hendak dicapai yaitu pembagian tugas dengan jelas untuk setiap anggota keluarga (suami maupun anak-anak). Subyek TR meminta keterlibatan anak-anaknya aktif membantu meringankan pekerjaan rumah.subyek VN yaitu mampu membagi waktu dengan baik, dapat mengelola keuangan serta istirahat apabila subyek mengalami kelelahan. Tahap VI Assessing, subyek VN, JN dan TR merasa bahagia dalam menjalani semua peranmendapat dukungan penuh dari keluarga.

\section{KESIMPULAN}

Penelitian ini bertujuan untuk mengetahui gambaran self-regulation pada mahasiswi strata satu yang berperan ganda sebagai ibu bekerja dari perspektif individu yang mengalaminya langsung yaitu wanita yang bekerja, ibu rumah tangga dan sebagai mahasiswa.Hasil penelitian ini menunjukkan bahwa para subyek penelitian berusaha membuat diri mereka masing-masing merasa nyaman dengan mengikuti alur yang tepat sehingga subyek dapat merasa bahagia saat menjalani semua peran.Adanya dukungan yang besar dari orang-orang yang terdekat seperti suami dan anggota keluarga lainnya menjadikan para subyek semakin bersemangat dalam menjalankan perannya gandanya. 


\section{DAFTAR PUSTAKA}

A, Bandura. Teori Kognitif Sosial Dan Teori Regulasi Dan Perilaku Manusia. Jakarta: Gramedia, 1991.

A, D, Alfiana. "Regulasi Diri Pada Mahasiswa Ditinjau Dari Keikutsertaannya Dalam Organisasi Kemahasiswaan." Jurnal Ilmiah Psikologi Terapan 01 (2013).

Alwisol. Psikologi Kepribadian. Malang: UMM Press, 2012.

B. J, Zimmerman. "Self Regulated Learning and Academic Achievment: An Overview." Educational Psychologist 25 (1) (1990).

Husna, Aftina Nurul, Frieda N.R. Hidayati, and Jati Ariati. "REGULASI DIRI MAHASISWA BERPRESTASI." Jurnal Psikologi Undip 13, no. 1 (April 15, 2014): 50-63. Accessed February 8, 2021. http://ejournal.undip.ac.id/index.php/psikologi/article/view/8066.

J H, Greenhause \& Beutell. "Sources Of Conflict Between Work and Family Role Academy of Management" (1985).

Moleong, Lexy J. Metodologi Penelitian Kualitatif. Bandung: Remaja Rosdakarya, 2017.

Sugiyono. Metode Penelitian Kualitatif Dan R\&D. Bandung: Alfabeta, 2010. 